\title{
Todos somos indígenas: Towards a New Language of National Political Identity
}

\author{
ANDREW CANESSA \\ Department of Sociology, University of Essex, UK
}

\begin{abstract}
One of the most striking aspects of 'Red October' was the central role played by indigenous groups and their leaders who were largely able to set the agenda of protest. This paper explores how the concept of indigeneity as a mobilising concept has moved from the periphery of the political arena to centre stage. Two indigenous leaders played significant roles: whereas the political rhetoric of Felipe Quispe is exclusionary and particularistic, Evo Morales's rhetoric is inclusive and broad. Indigenous identity as articulated by indigenous leaders is contrasted to the identities expressed by rural people and raises the question of how indigeneity is defined and by whom.
\end{abstract}

Keywords: indigenous movements, political rhetoric, identity and indigeneity.

\section{Introduction}

In a recent New York Times article, the 'indigenous movement' in Bolivia is credited with stopping the privatisation of water in Cochabamba as well as the overthrow of President Sánchez de Lozada: 'Indigenous people ... mov[ed] to wrest power from the largely European elite' in an article with the title, 'Where Incas Ruled, Indians are Hoping for Power' (Forero, 2004). Anyone familiar with Bolivia would have smiled wryly at the thought that there is a singular united indigenous movement and that the Water War in Cochabamba was part of it. It is not, however, simply for amusement that one looks at how events are reported in the international press; such interpretations have important repercussions for what happens on the ground in Bolivia.

The year 2004 was the last year of the UN Decade for Indigenous Peoples and this decade has seen not only the UN but the World Bank prioritise the position of indigenous people; it has witnessed the ratification of ILO Convention 169 on Indigenous and Tribal Peoples by most Latin American countries which has been 
successfully used by indigenous people; it has also seen countless NGOs, small and large, channel aid to indigenous groups for political as well as economic development. It is important to remember that the World Bank, the ILO and the UN all underline the importance of self-identification in their definitions of what it is to be indigenous.

It is also the case that indigenous groups and parties have dramatically taken centrestage in Bolivian politics, a process culminating in the December 2005 election victory of Evo Morales. That there has been an indigenous awakening (Wearne, 1996; Bengoa, 2000; Brysk, 2000; Stavenhagen, 2002) in Latin America generally, and Bolivia in particular (Albó, 1991), seems clear to all and it also appears to be the case that the Bolivians are much more likely than before to identify as indigenous, or, at the very least, as belonging to an indigenous group (such as 'Aymara' and 'Quechua') even if they do not identify as indigenous per se.

There are two points I wish to make in this paper. The first is that even though there has been a steady increase in 'indigenous mobilisation' over the past twenty years, it has changed profoundly in scope and content; the rhetoric of indigenous leaders is very much influenced by NGOs and international agencies and this may be in sharp contrast with the identities expressed by rural people who may not identify with the indigenous movement (local or global) at all. The second point is related to the first: if over the twentieth century the ideological model for the Bolivian citizen was the mestizo, will the twenty-first see an indigenous identity as ideologically dominant?

\section{Indigenism and Indigeneity}

One of the central paradoxes of the use of the term 'indigenous' is that it refers to people with a primordial identity, an enduring attachment to place, and cultures which have continued over centuries and millennia ${ }^{1}$ even as the concept itself is relatively new. Indigenous peoples and their cultures are seen as the last redoubts of local difference against the globalisation of culture, but the understanding that indigenous people in Canada and Indonesia and West Africa and Brazil share a common experience as 'indigenous peoples' is itself a product of globalisation (Hodgson, 2002). Indigenous leaders meet in many international conferences and it is often the case that they are much better linked to international networks than national ones. Even if indigenous leaders do not travel, they regularly work with international bodies informed by their own concepts of indigeneity and these, in turn, inform activists' understandings and political manoeuvring. Individuals embrace or contest the various images and languages of indianness and indigeneity in highly sophisticated ways (Warren and Jackson, 2002). As Gow and Rappaport (2002) have noted, this may produce a strategic discursive multilingualism in activists as they speak the

1 See Niezen (2003) but also definitions used by the World Bank (Davis and Williams, 2001: 5 (a); see also Revised Draft Operational Policy on Indigenous Peoples (Revised Draft OP 4. 10, 2005), the International Labour Organisation (ILO 169, Article One) and the United Nations (Martínez Cobo, 1986; see also DOCIP Update, No. 13, March/April 1996, Geneva). 
international language of indigenous rights to governments and NGOs whilst addressing those they represent in a different, locally situated, language.

The international language of indigenous rights has become a powerful one for many groups to articulate their concerns, especially given the failure of more traditional class-based politics to deliver for many people. In Asia and Africa this has caused some apparent anomalies. The Dalits in India, for example, are increasingly adopting the rhetoric of indigenism, claiming that they are the indigenous people of India who were invaded by Aryans, to further their political agenda. There is, however, no evidence that Dalits in north India are related historically to their southern counterparts; indeed there is considerable evidence to the contrary. There are many 'tribal' groups in India who are redesignating themselves as indigenous even though their migration into India is a matter of historical record. In Botswana, home to half the Bushmen/San peoples of Southern Africa, the government refused to attend the 1993 International Conference on Indigenous Peoples because, it declared, everyone in Botswana is indigenous (Lee, 2003: 84). In neighbouring South Africa the Bushmen/ San are widely recognised as being indigenous even by the related Khoi groups (Lee, 2003).

In Latin America, too, political protest has been indigenised (Brysk, 2000) but we should not assume that identifying indigenous groups is necessarily a straightforward matter in Latin America either. At first glance the situation seems abundantly clear: the descendants of those who inhabited the continent before 1492 are indigenous and those descended from later arrivals are not. According to this formulation the descendants of Inka colonists who arrived in Bolivia in the final decades of the fifteenth century are indigenous whereas the descendants of the Spanish colonists who arrived in the beginning of the sixteenth century are not.

There is, without a doubt, a level of arbitrariness about defining indigeneity and much ink has been spilt on discussions of the issue (see Eriksen, 1993; Hodgson, 2002; Maybury-Lewis, 2003). This paper will not concern itself with discussions of whether anyone or any group 'really' is indigenous or more indigenous than others but I do want to note the growing worldwide understanding shared by international agencies and activists alike that indigenous people are marginalised, often poor; victims of economic and political injustice; and bearers of 'traditional' culture. The claim to indigenous status is therefore a claim to authenticity and a claim for justice. It is through the lens of this globalised understanding of indigeneity, rather than any local version of it that I wish to view the events of 2003 in Bolivia. These events, I will argue, mark a profound change in the nature of indigenous protest, mobilisation, and identity in Bolivia.

There can be no doubt that indigeneity is enjoying a high profile in Bolivia and many other Latin American countries. After decades and centuries of contemporary indigenous culture being represented as anachronistic, backward and retarding the progress of the nation, 'the indigenous' is now increasingly seen as being iconically national. At its most trivial level, tourists can buy indigenous handicrafts as souvenirs in every Andean international airport as 'typical' and 'authentic' national souvenirs. There is, however, some ambivalence to this celebration of indigenous culture: the particularity of indigenous culture and language can be presented as marking the genuinely national even as it serves as the marker of social and racial inferiority. In 
Bolivia today the ability to speak an indigenous language is highly valued among educated urban people as it is a useful passport to a job with an NGO; but speaking an indigenous language as a rural and uneducated person continues to serve as a marker of one's inferior social status. Chewing coca in rural areas is similarly a marker of inferior indianness but when it is done in jazz bars in La Paz it is 'cool'.

Indigeneity as an identity is highly contextual; and tourist images of indigeneity, colourful and exotic, bear little resemblance to the lives of real people; moreover, they can serve to dictate to indians the parameters of their own identity by defining what is 'properly' indian or indigenous.

Indigeneity as a concept relating to humans, as opposed to plants and animals, according to one commentator (Niezen, 2003: 2), has been in wide use for little more than twenty years. This may be true in the English-speaking world; but Latin America has a long history of indigenismo. Indigenismo seems an obvious translation for 'indigenism' but there are significant distinctions between the two. For the purpose of this paper I will distinguish between 'indigenism' and its cognate, 'indigeneity', as a contemporary global phenomenon and indigenismo, a twentieth-century intellectual and artistic movement that sought to valorise indigenous culture. In Latin America indigenismo was a powerful discourse, particularly in the first half of the twentieth century but with important consequences in the second half as well. Indigenismo was, however, about mestizaje more than it was about contemporary indigenous peoples, whereas contemporary indigenism is far more about indigenous people as political and cultural subjects in their own right. If indigenismo was accompanied by a strong impulse to assimilate indians, it is worth asking if indigenism has the potential to assimilate mestizos.

\section{Indigenismo}

Indigenismo was first and most clearly articulated during the Mexican Revolution by intellectuals such as Manuel Gamio and José Vasconcelos but later spread to many other Latin American countries, including Bolivia. At its roots, indigenismo was an essential aspect of the ideology of national ethnogenesis, the creation of a new national identity based on the mestizo. This idea of the mixed race person being at the centre of a new national ideal became widespread in Latin America during the course of the twentieth century (Graham, 1990; Wright, 1990; Wade, 1997). Indigenistas in the twentieth century were, however, almost invariably, mestizos and creoles who focused heavily on the indigenous past rather than on contemporary indigenous people; indeed, indigenismo can be understood both as part of the process whereby the rising Latin American elites became comfortable with their own mixed heritage and as an ideology of engagement with the creole landowning oligarchy. What is absolutely clear is that indigenismo is about a mixed heritage, not an indigenous one: the mestizo is the iconic citizen.

Mestizo in this context must be understood as an ideological and historical term no less than 'indigenous' or 'indian'. As Harris (1995) has pointed out, in some cases being mestizo amounts to little more than not being indian. By mid-century in Bolivia the 
mestizo was part of the national project of creating an urban, Spanish-speaking middle class as well as a rural proletariat, and consequently the indian was erased in favour of a mestizo identity in the 1952 revolution. As part of this process indigenous culture was glorified, but as folklore rather than contemporary culture: in order to create a new national identity the state sponsored folklore festivals, encouraged folkloric dances in schools and enabled folklore troupes to tour Latin America. In many of these instances the troupes were exclusively or primarily composed of mestizo-creoles (Bigenho, 2005). Indigenous culture as it became national culture was folkoric and the principal nationbuilding project was to assimilate indians into a national mestizo Spanish-speaking culture. As many have commented, the educational system was particularly directed to this end (Choque, 1992; Canessa, 2004).

If the second half of the twentieth century in Bolivia was dominated by the belief in redemptive mestizaje, the forging of a new nation and new race, the politics of the 1990s showed that to have been a mirage at best. The two most prominent indigenous leaders of Bolivia in the last decade, Felipe Quispe and Evo Morales, have contrasting visions of indigenism, which will be discussed in greater detail below. Both visions, however, can be seen as a rejection of traditional indigenismo and its concomitant elevation of the mestizo; they owe much more to the global concept of indigenism than to indigenismo.

\section{Indigenous Protest}

For much of the latter half of the twentieth century, indigenous movements in Bolivia were weak and muted. In the highlands Fausto Reinaga's Partido Indio Boliviano served as the inspiration for some, ${ }^{2}$ but most Bolivians, it seems, believed the universalising rhetoric of the revolution and identified as campesinos rather than indios. Protest was based on class rather than ethnicity and it appears there was very little conceptual space for an ethnic-based movement in the highlands. The 1952 revolution successfully co-opted indigenous people into a syndicalist structure as rural workers: indians were to be transformed into unionised peasants. Indigenous co-optation was even more profound under the military-peasant pact, which did not reach its demise until the 1970s. At the same time, labour organisations did not develop an indigenous critique or agenda because their class analysis left no room for it; indeed, they were often wary of peasants because of their status as petit bourgeois small landowners.

The failure of class politics to secure advances for common people led to the ethnicisation of political protest, particularly arising out of the CSUTCB. The Tiwanaku Declaration of 1973 and the establishment of katarista Aymara nationalism in the highlands led to two decades of factional katarista politics. Despite having

2 Indeed, both Evo Morales and Felipe Quispe claim inspiration from Reinaga, Quispe having met him in 1971. Felipe Quispe makes reference to Reinaga with some frequency and Reinaga's racialised politics would certainly seem to resonate strongly with Quispe. Somewhat more surprising, perhaps, is that Evo Morales (2005), in an interview published on his own website (http://www.evomorales.net/Castellano/pages/ not010415.htm), cites Reinaga as the politician/writer who had the greatest influence on him in his youth. 
potentially large numbers to draw into their new ethnic politics, katarista parties and groups failed to reach out beyond their altiplano Aymara base and had virtually no success in electoral politics (Albó, 2002). ${ }^{3}$ The Andean highlands are where the majority of Bolivia's indigenous population lived and lives and where they have the organisational advantage of speaking one of two indigenous languages and sharing many cultural attributes and practices. It was nevertheless the lowlands, where indigenous people were much more marginalised, much more dispersed and much more heterogeneous, that produced the most dramatic and powerful example of indigenous mobilisation in the 1990s.

\section{March for Territory and Dignity}

In Bolivia, one of the clearest and most public indications of the 'indigenous emergence' (Bengoa, 2000) was the 1990 March for Territory and Dignity. This March had a profound effect on the consciousness of Bolivian elites, provoking, according to Albó (1995), resonances with the siege of $\mathrm{La} \mathrm{Paz}$ in 1781 by Tupac Katari. For some residents, Katari's prophecy of returning in millions and millions seemed to be fulfilled. What is certainly the case is that such a large protest, which received considerable national and international attention, brought indigenous concerns into national politics and was sufficient to persuade the government to recognise the territorial rights of lowland indigenous groups.

The 1991 March fitted very well into the model of indigenous protest in Latin America up to that point: lowland indians mobilising to defend their territory. Although highland Aymara and Quechua-speakers joined the march at its later stages, it was principally organised by and for lowlanders with specific demands. It is also worth noting that in 1990 very few people self-identified as Aymaras and Quechuas and most highlanders had, at best, an ambivalent identification with lowland indigenous groups.

The 1991 March offers a good example of a 'new' social movement: it was a singleissue protest not based on an historical class alliance and had a very specific aim which was the recognition of indigenous people's territorial rights in the context of the incursion of loggers and other colonists. The issue of cultural rights and values was strongly presented, as is the case for many new social movements (Touraine, 1988), and issues of identity were pushed to the fore (Melucci, 1989). Here, as with many other indigenous movements, their political aims were presented as being identical to the aims of preserving the environment and protecting natural resources. This marriage of indigenous rights and ecological concerns had proven to be successful in applying pressure to governments, as the international environment movement has long seen

3 Katarista politics of the 1970s and 1980s had, however, a profound effect on contemporary indigenous politics. Most obviously Felipe Quispe was part of an armed katarista movement of this period and Victor Hugo Cárdenas' vice-Presidency, although compromised and ultimately discredited in the eyes of many other kataristas, did nevertheless demonstrate that there was a national and international space for expressing indigenous ideas. 
indigenous people as natural allies, even if there has been considerable disillusionment about the alliance in recent years (Graham, 2002). It is worth noting that international NGOs had a prominent role in organising indigenous groups for the March (Patzi, 1999). The role of international NGOs in this and other mobilisations has remained significant and underlines the globalised context in which such mobilisations occur; indigenous mobilisations are never simply local events.

The 1991 March was dramatic and bold and, as it was reported all over the world, it severely embarrassed the government, which rushed through a law protecting indians' lands (which is still being disputed in the courts). Once their aims were achieved or appear to have been achieved, the marchers maintained only a tenuous link with each other. Lowlanders and highlanders marched again on La Paz in 1995, once again over the issue of territory: but this time there were eleven deaths, as well as disagreements between the groups, and the formal coalition was disbanded (Gustafson, 2002: 282).

The 1991 March did, however, have some consequences, not least of which was the recognition among some sections of the urban population that the large indigenous population of the country was not going to be assimilated into a mestizo nation-state. It is probable that the March was one of the factors that prompted Goni to choose the katarista Victor Hugo Cárdenas as his running mate in the subsequent election and for the MNR to campaign, for the first time, on a platform of multi-culturalism. The March is also credited with providing the impulse for the 1993 Law of Constitutional Reform, which recognised indigenous rights for the first time in modern times (Van Cott, 2002: 53). The multicultural pluriethnic discourse that followed for much of the nineties was one of a Bolivia which included difference, made up of component parts which together formed the national whole.

If the fact that after 50 post-revolutionary years the existence of indigenous people was formally recognised and celebrated is to be welcomed, one also needs to note that indigenous issues continued to be marginalised. Victor Hugo Cárdenas owed his position to the munificence of Goni and throughout the nineties indigenous parties polled very poorly in national elections. It is also worth nothing that, despite being the catalyst for this profound change in the national imagination, lowland groups have largely lost the political initiative and remained largely marginal to national political processes in the decade to follow. This is perhaps more due to changes in the organisation of municipalities than any visionary seizure of political initiative by highland groups.

The 1994 Popular Participation Law, however, changed the structure of local politics which became much more decentralised. Three hundred and eleven local municipalities were created in a move that was seen by many as the government relinquishing responsibility for local communities. By the end of the decade, however, 29 per cent of the elected officials of these municipalities were indigenous, even if they were not themselves members of indigenous parties (Albó, 2002: 82): in municipal elections the indigenous vote, and consequently representation, was spread over a very wide range of parties. One of the key points here was that indigenous issues qua indigenous issues were not of interest to a wider electorate and were apparently not even particularly interesting to the vast majority of people who might be described as indigenous. 
The growth of indigenous representation in municipal elections does not, however, in itself, explain Evo Morales's success in the 2002 election where he came second place to 'Goni' Sánchez de Lozada, receiving almost 21 per cent of the vote (to Goni's 23 per cent); nor does it explain his increasing profile since then and his prominent role in the ousting of Goni in October 2003. It certainly does not explain his stunning victory in the December 2005 presidential election, where he polled an unprecedented $54 \%$. Part of Morales's success is due to his ability to articulate wide-spread anxiety about the effects of economic globalisation and in this he can be located in a tradition of populist leaders such as Max Fernández and 'el compadre' Palenque. Palenque, in particular, and even though he was not indigenous himself, was also adept at invoking the urban indigenous culture from where his largest support came. Morales, however, focuses particularly on the feeling that Bolivia's natural resources are being exploited by multi-national companies with few tangible benefits for the mass of Bolivians. This concern became most evident in the city of Cochabamba in 1999 and 2000 in a struggle for control of the city's water.

\section{La Guerra del Agua 1999-2000}

Between the March for Territory and Dignity and the Gas War (i.e. the 2003 uprisings) there is, of course, the Water War. The Water War in Cochabamba was clearly a forerunner of the Gas War in that the experience in Cochabamba showed that broad coalitions could be mobilised successfully against multinational companies in the protection of natural resources. The leadership of the Coordinadora de Defensa del Agua y de la Vida was neither indigenous nor rural: criollo and middle class mestizo Cochabambinos predominated. They were, however, able to articulate the concerns of rural Quechuaspeaking irrigators, Quechua-speakers of the urban periphery, as well as coca-growers in the region. None of these groups in the 1990s had a strong indigenous identity in the 1990s: there was a strong regional identity, especially relating to the Valley of Cochabamba; there was a strong class identity on the part of the peasants in the valley as well as of the coca-growers; there was also a political history of sometimes violent resistance to the state to draw upon; but a specifically indigenous identity would not, at the end of the decade, have been particularly prominent across these groups.

However, as Laurie et al. note, a new 1999 water and sewage law (Law 2029) recognised the importance of existing uses and customs, usos y costumbres. 'Recourse to a language of usos y costumbres invoked a seemingly untouchable set of inherited rights with their basis in customary law and Andean spirituality' (Laurie, Andolina and Radcliffe, 2002: 265). The leaders of the movement were quick to recognise the importance of adopting the language of indigeneity not only in the hope of engaging Quechua-speakers in the valley of Cochabamba (Laurie, Andolina and Radcliffe, 2002) but also to attract the interest of an international press which was accustomed to reporting indigenous rights issues and environmental concerns as one and the same.

Laurie et al. have stressed how important it was for the Coordinadora to communicate an alliance with rural, indigenous peoples even as the rights of the communities to be affected by the Misicuni dam were totally discounted. The protesters regularly invoked the Pachamama, an Andean deity, in their slogans in order to underline the 
indigenous and even mystical connection between water and people as well as their ancestors. Other deities such as Wiracocha and Tata Dios were also mentioned. Laurie, Andolina and Radcliffe (2002) note a key poster in the January uprisings saying, 'Water is Ours. Pachamama, Woracocha (sic) and Tata Dios gave it to us to live, not to do business with'.

The Pachamama is the one Andean deity who is likely to be well known to urban Spanish-speakers. The creator god Wiracocha is rarely mentioned by contemporary indigenous people although, again, many urban people are familiar with the myth that the Incas confused the Spanish with this god, Wiracocha. Tata Dios is a simply translation into Quechua/Aymara of 'God the Father' in Spanish. The word 'Pachamama' is often translated as 'Earth Mother', a concept easily assimilated by non-indigenous Bolivians. She has even appeared in the inflight magazine of the state airline, where she was described as the 'mother of all Bolivians' (Harris, 1988).

None of these deities, however, is particularly associated with water. Tata Dios is more often associated with the destructive forces of nature such as hail or the burning sun which scorches crops, that is in this sense he is opposed to water. Although the Pachamama is an important contemporary deity she is associated with the earth, not water. The water gods bring rain and allow her land to grow crops, but she herself is not generally associated with the bringing of water or its origins. As far as I can establish, the traditional water gods, the apus or achachilas, were not mentioned at all.

As the Coordinadora's language developed over time it increasingly used an indigenous rhetoric but this does not seem to have come from the indigenous people in the coalition but, rather, from urban mestizo-creoles who understood the potential potency of defending their interests with the language of indigeneity.

The water protests in Cochabamba were ultimately a success and served to illustrate that the defence of national or regional interests could be effectively prosecuted in terms of a 'natural' attachment to land and resources, of a particular relationship between people and territory and one that was a frequently imbued with a certain mysticism.

If the March for Territory and Dignity demonstrated that indigenous demands could be successfully allied with concerns about the environment and natural resources, the Cochabamba protests a decade later demonstrated that indigenous imagery and rhetoric were strategically useful in presenting concerns about natural resources. They were both, however, issue-specific and despite creating large coalitions and great publicity, they did not sustain themselves over time. The Gas War, however, differed in important respects from both of these earlier movements. But before I discuss the events of 2003, I would like to compare the two most prominent indigenous leaders in this period, Evo Morales and Felipe Quispe.

\section{Evo Morales and Felipe Quispe}

Morales and Quispe were both born in Aymara-speaking homes on the altiplano and both forged their political careers in union-based politics. Both, in fact, were involved in the CSUTCB, but Quispe has successfully and successively prevented Morales from achieving any leadership position within it. Morales was forced to continue to develop 
his political base in the Chapare among highland immigrants whereas Quispe has developed his base in the Aymara-speaking regions of the La Paz altiplano and his attempts to reach out beyond his Aymara base have largely failed.

Quispe's model of indigenous politics is famously separatist, and his language is sharp, stark and racialised. Quispe, who spent several years in jail for terrorism, adopts a rhetoric which many perceive as extremist and all of the deputies and candidates of his party are indigenous. Morales in contrast, as Quispe has pointed out, lets mestizos and creoles into his party and this, for Quispe, is one of the key differences between the parties: MAS is simply not an indigenous party as far as Quispe is concerned.

Morales wears his indigeneity much more lightly: he certainly refers to his indigenous roots, describing himself as being of 'Aymara nationality'; but he is careful to avoid presenting himself and his party as simply an indigenous party, even as he lays out his programme with regular reference to indigeneity. Rather than seeking to supplant the nation-state, MAS's rhetoric is about defending Bolivia from the forces of globalisation.

If Quispe's indigenism is resolutely exclusive, the language of Morales and MAS is much more inclusive. For a start, Morales has neither a specifically Quechua nor an Aymara base: he was born into an Aymara-speaking community but migrated to the tropical and predominantly Quechua-speaking lowlands in the early 1980s. He is frequently reported in the press as speaking both languages, although there is some debate as to whether he speaks either at all (Albro, 2005). On some occasions he is described as a Quechua, on others an Aymara and sometimes both. In his own person he seems to incarnate a pan-indigenism.

Quispe's indigeneity is much more specific and much more hostile to the current nation-state. The Mallku, as he is usually referred to, is very much an Aymara politician with a strong base in the highlands around La Paz and he has enjoyed very little success beyond his Aymara heartlands despite adopting as his vice-Presidential candidate in the last election a Quechua-speaking woman, Esther Balboa, well connected to the pan-indigenist movement and who tends to wear a Maya huipol. Quispe's vision of the future is one where the current state is replaced by an indigenous nation. $\mathrm{He}$ is patently hostile to Bolivian nationalism and even wants to change the name of the country to the República de Qullasuyu (the Inka term for what is now much of Bolivia); create an Aymara military High Command; and replace the Department of Indigenous Affairs with a Department for Gringo Affairs for those mestizo creoles that remain after the revolution.

Quispe's language is often highly racialised; he talks openly and frequently about 'eliminating' whites and mestizos and also those of the new indigenous elite with their own successful businesses: 'se ve que hay unos cuantos, que tendrán sus casas ... entonces nosotros tendríamos también que eliminarlos' (Vinelli, 2002). Quispe often uses the pejorative q'ara to refer to white people. Q'ara in Aymara means literally 'bare' but in this context describes someone denuded of culture and moral values. In an interview with the author in 2005 (Felipe Quispe, 2005), Quispe also used the phrase 'jayata jutiri' which literally means 'those who come from far away', a phrase which succinctly contrasts the indigeneity of indians and the foreignness of white people. In a recent interview with the author, Quispe explains his policy towards q'aras: 
Those lying q'aras. When the Pachamama walks again in Qullasuyu, when her laws reign, then we will be able to judge them. Those who want to leave can go; but those who stay will eat what we eat; they will work the way we work, dripping with sweat; they will have blisters on their hands; they will suffer like we do. Then truly the Aymara nation, what people call the indigenous [nation], what we call Qullasuyu, will come forth. We won't kill them, we won't do anything to them: we won't hate them the way they hate us; we will embrace them and that is how we will unite as brothers. We will be as one single trunk, one single way of thinking; and we will arrive at a way of thinking to live in a free and sovereign nation, without tears in our eyes. That is what we think, brother. ${ }^{4}$

Quispe's vision is for a new nation and one that depends on an indian revolution. Morales's vision, in contrast, is not to replace the nation state but to defend the patria and he does so by making indigenous concerns, national concerns. In a recent article in Los Tiempos (August 2004) of Cochabamba Morales is reported as seeking to defend those national interests against the United States and globalisation in general by seeking the re-nationalisation of gas.

MAS is careful to avoid the sectarianism of the Mallku and directs its message to a broad social sector. The mission statement of MAS roots its politics in an indigenous consciousness, the 'producto del resurgimiento de las movilizaciones de los pueblos originarios' and allies itself to the continental pan-indigenous movement. It does, however, open out to much broader concerns including the black movement and the popular movement:

Formado por auténticos representantes de los pueblos indígenas, campesinos y obreros el MAS es, actualmente, la expresión de todos los sectores marginados de la sociedad que, oprimida por el modelo neoliberal y por la globalización, lucha por sus reivindicaciones, por su identidad, su autodeterminación, la soberanía y la dignidad. (Movimiento al Socialismo, 2005)

4 Uka k'ari q'aranakaxa aka Qullasuyu Pacha Mamana sartawipa utjxani ukjaxa, kamachinakapasa utjxani, ukhamarakiwa ukanakaru taripañasa utjxani, ukanakaxa khitinakatixa sarxä sani ukanakaxa sarxapxpana markanakaparu, pero khitinakatixa qhiparani aka markaruxa nanakjamaraki manq'pana kuntixa manq'apxktha uka, nanakjamaraki irnaqpana, jump'isa ch'aqarata, ukhamaraki amparanakasa akhama q'ala wali phallarata, wali t'aqhisita sarnaqapxpana, ukjakirakiwa chiqpachansa aka aymara marka ukhamarakiwa aka khitinakatixa indígena sutichatapxktha uka marka Qullasuyu marka nayraqataru apsupxiristha, janiwa nanakaxa jupanakaru jiwayapxkäsa, janiwa kamachapxkäsa, janiwa jupanakaru uñisipxkäti, kunjamti nanakaru uñisipxkitu ukhama, jani ukasti nanakaxa jupanakaru munthapisipxawa, ukhamawa maya suma wawaru tukusina maya lawaru maya amuyt'aru sarnaqañaxa utjaspa aka markana suma qhapaqkankañana, jani jacha nayrani llakita, ukawa nanakana amuyujaxa jilata. Interview with the author, Felipe Quispe (2005). 
It is quite clear that MAS is first and foremost a coca-growers' union, but it has gone beyond the politics of particularism to address issues that clearly resonate with Bolivians who are neither coca growers nor even remotely indigenous. One of the interesting things about MAS is how it strategically marries a class discourse with an ethnic one and combines both in a broad anti-globalisation discourse. So, for example, in the MAS journal Soberanía one can read articles on the war in Iraq (for example, Hylton, 2003) and other global issues as well as those relating to Bolivia and cocagrowers.

In a December 2003 interview published in Counterpunch, Evo Morales articulated very clearly this shift from indigenous identity politics to a critique of neoliberalism, capitalism and the world economic order and a defence of environmental issues:

After more than five hundred years, we, the Quechuas and Aymaras, are still the rightful owners of this land. We, the indigenous people, after five hundred years of resistance, are retaking the power. This retaking of power is oriented towards the recovery of our own riches, our own natural resources such as the hydrocarbons. This affects the interests of the transnational corporations and the interests of the neoliberal system. Nevertheless, I am convinced that the power of the people is increasing and strengthening. This power is changing presidents, economic models and politics. We are convinced that capitalism is the enemy of the earth, of humanity and of culture. The US government does not understand our way of life and our philosophy. But we will defend our proposals, our way of life and our demands with the participation of the Bolivian people (Dangl, 2003).

Morales swiftly moves from identifying himself specifically with the 'Quechuas and Aymaras', then more broadly with 'indigenous people' and finally with the Bolivian people more generally. In a similar vein he locates his indigenous identity and resistance and moves to comment about 'natural resources'. By the end of this brief quote Morales is talking about the earth and humanity, thus illustrating the breadth of his political message, which goes far beyond the concerns of coca growers in the Chapare.

Morales's indigeneity here is a strategic position against which to challenge global capitalism. If we understand globalisation as the extension of global capital in ever more efficient ways which has as one of its consequences the weakening of the nationstate and the homogenisation of products and cultures around the world, then what could be more anti-global than an indigenous identity? If globalisation is about rampant world capitalism, indigeneity is about local economies and practices. If globalisation is about neo-colonial exploitation of resources, then eco-indians are the best guardians of natural resources. If globalisation is about deterritorialised and fractured identities, indigeneity is about an enduring, rooted and authentic identity.

But globalisation is, of course, multi-facetted and one can equally emphasise the flows of information and expansion of networks (Castells, 2000). One of the ironies of globalisation is precisely that it allows local groups access to international technologies 
and networks, not to mention concepts such as indigeneity and international human rights, with which to oppose other aspects of globalisation.

It is worth remembering that what prompted the Zapatista revolt in Mexico was the North American Free Trade Association and the Zapatistas have certainly framed their political struggle in terms of defending Mexico (and they claim to be proud to be Mexican) in terms of indigenous values. When indigenous groups in Ecuador conspired with the army to overthrow the government of Jamil Mahuad in January 2000 they did so on the grounds that they were protecting national interests, rather than indigenous interests.

This displaces the discussion as to whether MAS is really an indigenous movement and Evo Morales really an indigenous leader. Evo Morales's origins are as indigenous as any highland person can claim and his coca-grower base is overwhelmingly constituted by Quechua and Aymara-speaking peasants, migrants from the highlands. If a movement is composed of indigenous people, does that make it an indigenous movement? If Evo Morales is a leader who is indigenous, does this make him an indigenous leader? The answer can only be no if one limits 'indigenous issues' to a limited range of territorial and cultural rights. This very issue confronted the Zapatistas in 1994 who responded with:

We are thousands of indigenous people up in arms, and behind us are
thousands of people in our families. Add it up; we amount to many
thousands of indigenous people in struggle. The government says that
this is not an indigenous uprising, but we think that if thousands of
indigenous people have risen up in struggle, then it must be an indigenous
uprising. (CCRI-CG 1994 in Stephen, 2003: 195)

Evo Morales has clearly studied the Zapatista rebellion (he is fond of quoting some of their slogans) (Albro, 2005) and it is not surprising that as he is fêted globally as an indigenous leader, he is well aware of the strategic uses of the language of indigeneity. One of the greatest successes of MAS and Morales is their ability to go beyond the interests of coca growers and to avoid the racialised nationalism of the Mallku and articulate an indigenous political programme with far broader appeal. At the root of this is an understanding of the power and appeal of the globalised idea of indigenous people as authentic and as victims of injustice.

As every European and US school child 'knows', indigenous people are more 'ecological', more at one with nature. This is part of what Ramos (1994) has called the 'hyperreal indian' but the global hyperreal indian gets recirculated and provides a powerful reference for local groups to assert their rights over natural resources. This is the context in which indigenous groups can then lay claim to having the true interests of the nation at heart: what better custodians of the nation's resources than indians rooted to the land?

It is for this reason that the Water War in Cochabamba invoked the language of ancestry, the Pachamama and the sacredness of the land - iconic indianness. The Water War protesters' principal leaders and coordinators were not predominantly indigenous but that did not prevent the foreign media such as the New York Times from representing them as indigenous people fighting the forces of globalisation. One of the 
striking differences between the two 'wars' is that whereas the Cochabamba Coordinadora was dominated by mestizo-creoles who reached out for a coalition with rural indigenous people, the Gas War was much more about indigenous political groups successfully forming coalitions with other sectors of society but maintaining considerable control of the agenda. In the Bolivian Gas War indigenous groups were much more clearly at the forefront, especially Quispe and his ability to mobilise large groups of people in blockades. Morales played a less prominent role in Bolivia apart from his role in the march of 19 September 2003. He appears to have spent much of the time abroad and, quite possibly as a direct result, achieved a very high profile in the international media. Once Goni was ousted he ended up as a significant powerbroker and was instrumental in supporting the Mesa administration in its first weeks and months.

Morales is clearly profoundly influenced by globalised discourses on indigeneity but it is not only he who is capable of deploying romantic imagery; Quispe too, for example, has described the gas issue in relation to the Pachamama earth mother: 'The absolute truth is that [the gas] comes from the Pachamama's belly, it is as if it were her breath. The gas escapes as if she were letting out a fart. That is how the gas comes out of our earth'. ${ }^{2}$

Of course, one must consider that Morales and Quispe will deploy different imagery depending on their audience; when addressing coca growers, Morales focuses much more on their specific issues and Quispe in his rallies similarly focuses on issues of poverty and social revolution. That is, they are both discursively multilingual in Gow and Rappaport's (2002) terms. On a local level Morales is perhaps more closely associated with his anti-globalisation and anti-American stance than his indigenism yet Albro notes the careful use of indigenous imagery of the kind mentioned above in his local rallies (Albro, 2005). Quispe, too, in interviews on Aymara language radio and rallies reported to me by Aymara informants speaks of the pachakuti [indigenous cosmological revolution], the four pillars of Aymara culture (see below), as well as the Inkas and the Tiwanaku civilisation in ways not immediately familiar to local audiences. It is not simply that these leaders are adept at tailoring their speeches to different audiences but also that there is a constant circulation of ideas from the international level to the local and back again. Not only have indigenous people gone from the margins to the centre of Bolivian politics; but, rather more interestingly, it appears that central political issues, national issues that affect everyone, are represented as indigenous issues - after all, there is nothing intrinsically indigenous about a gas pipe line. Indigeneity is becoming the language of protests over resources and the defence of the patria against the forces of globalisation; it is breaking out of its specific concerns and offering a language of political engagement for a much broader public.

If 'new' social movements are identified by their single issue and narrow identity base, the politics of MAS and October 2003 do not fit easily into such a framework. The protestors were articulating concerns about globalisation, constitutional reform, state corruption and the defence of coca-growers through the language of class and indigeneity.

5 Ukaxa qhanpacha arunxa Pacha Mamana purakapata mistsu, maya samanapakaspasa ukhamawa, ukata maya thisiñakaspasa ukhamawa mistsu, ukaxa nanakana uraqijata mistsu. Interview with author, Felipe Quispe (2005). 
This latter point is of particular significance since the rhetoric of MAS is carefully balanced between articulating the rights of workers and expressing an indigenous worldview. The result is a particularly powerful language of political engagement.

Evo Morales is also quite capable of romanticising indigenous culture for political ends. His 'strategic essentialism' is common to many indigenous activists who have to walk the tightrope of accurately representing their supporters whilst articulating a political language that is effective in a wider public domain. This is itself is not unusual; what is unusual about MAS is the potential for an indigenous political ideology to become mainstream.

In an earlier paper (Canessa, 2000) I noted that highland indigenous people were increasingly rejecting the politics of mestizaje, the twentieth century vision that the Latin American nation comprised indigenous and European elements in a productive fusion. Decades of co-optation, marginalisation and racism were propelling people away from the belief that assimilation into the mestizo nation was a progressive option; and towards the less compromising identities represented by katarismo and evangelical Protestantism; katarismo and evangelismo represent opposite poles of rejection of the mestizo centre. The former, represented by Quispe, has clearly increased in prominence, and the spread of evangelical Protestantism certainly shows no sign of waning. ${ }^{6}$

The politics of Evo Morales and MAS, however, does not fit this model of polarisation at all: rather than reject any possibility of a politically inclusive middle ground he has replaced the mestizo as the iconic citizen with the indígena. Morales avoids the anti-Christian rhetoric of Quispe (Qhispe Wanka, 1990: 140-143) whilst simultaneously offering an indigenous vision of a future Bolivia. It is difficult to see how MIP could attract significant evangelical support but the platform of MAS is certainly appears more palatable to the growing population of indigenous evangelicals.

\section{A New Indigenismo?}

As MAS's resounding success in the December 2005 elections attests, its politics offer something for a wide range of Bolivians: an inclusive ethnicity; a sense of authenticity; and a powerful critique of globalisation. The coca leaf has become the emblem of what is unique about Bolivian culture, its authenticity and something to rally behind in opposing globalisation. Upper class Bolivians chew coca in Sopocachi bars. I know of creoles who have hired yatiris to ch'alla their new houses in the elite zona sur of La Paz. Is this merely old style indigenismo or could these phenomena transform themselves into a wider identification of indigeneity? If the mestizo was the model for Bolivian identity in the twentieth century, will the indigenous person take that role in the twenty-first? ${ }^{7}$

6 Unfortunately the 2001 census did not ask about religious affiliation but there is considerable anecdotal evidence to suggest that ever-increasing numbers of people are joining Protestant churches.

7 Bolivia would not be unique in this experience, as other countries have experienced a new politics based on a loose ethnic identification. Donna Goldstein's (1997) work in Hungary documents how thousands of people recently discovered their Jewishness and how Jewishness has become associated with a particular liberal, cosmopolitan politics. 
The last Bolivian census records 63 per cent of the population as declaring an indigenous identity (Instituto Nacional de Estadísticas de Bolivia/UMPA, 2003: 157). There is sadly no comparable data from previous censuses but it had been generally assumed for decades that indigenous identity was linked to language use, which was in decline. ${ }^{8}$ Numerous qualitative studies showed that in the twentieth century many indigenous people stopped identifying themselves and stopped being identified as indigenous when they migrated to urban centres. That urban migration, with its concomitant exposure to racism and loosening of communal ties, has the effect of weakening ethnic identification has become part of accepted anthropological wisdom (Harris, 1995). One of the diagnostics of change in ethnic identity is language shift and there is no doubt that indigenous languages are giving way to Spanish, especially in urban areas. A majority of Bolivians now have Spanish as their mother tongue; yet an even greater majority identify as indigenous. Indeed, only half of the population (49.4 per cent) now speaks an indigenous language either as a mother tongue or second language (Instituto Nacional de Estadísticas de Bolivia/UMPA, 2003: 143); and many of these will not be fluent. This is far short of the 63 per cent identifying as indigenous, which clearly indicates that language is a very poor indicator of indigenous identity.

What is striking about the 2001 census is that almost exactly half of those identifying as indigenous live in urban areas, a fact which has received virtually no comment. There is every indication that urbanites are changing their habits and large numbers of people are identifying as indigenous even if they do not live in an indigenous community or speak an indigenous language. At least some of these people are individuals who in most contexts would be considered unambiguously white: I have heard the son of German and Polish immigrants declare himself to be indigenous; and another creole comment that 'all Bolivians are indigenous; I am indigenous'; and yet another that 'we are all indigenous' ('todos somos indígenas'). It is not only mestizos and creoles who claim that 'we are all indigenous': internationally-known indigenous leader Gualberto Choque, Executive Secretary of the Federación Departamental Única de Trabajadores Campesinos de La Paz 'Tupaj Katari', claimed the very same thing when presenting a book published in Mexico on indigenous movements, Movimiento Indígena en América Latina, in La Paz in 2005. Choque contributed a chapter to the volume and in an interview following the presentation he illustrated how one could have a highly romanticised vision of indigenous identity which included a long discourse on the Pachamama and indians' ecological practices with a highly inclusive view of indigeneity: 'Not all white people live well. Some [poor] white people live here. White people and black people and we the Aymara people, we will all unite. Once we unite in this way there will be one great way of thinking; and that is what we will call indigenous'. ${ }^{9}$ Choque is quite clear that the essential elements

8 In 197634 per cent of the Bolivian population was monolingual in Spanish, rising to 42 per cent in 1992 and 47 per cent in 2001 (60 per cent in urban areas).

9 Janiya taqpacha jaq'uxa wali suma qamaskitixa, janq'unakaxa utjiwa akanxa, t'aqhisisarakiwa akana qamaskapxi, janq'unaka ch'iyaranaka jiwasanaka aymaranaka taqipuni mayaruki tukt'añani, mayaru tukt'asasti ukjaya maya jach'a amuyt'awi apsuñanixa, ukaya indígena sutinixañanixa. Interview with author, Gualberto Choque (2005). 
of indigenous thought are ecological practices, the sharing of resources, and anti-capitalism. It is therefore not simply mestizo-creoles who are co-opting an indigenous rhetoric but also that many indigenous leaders are explicitly offering them a set of values which can be shared, although few, perhaps, would express such an ecumenical view as Choque.

If self-identification as indigenous is not dependent on a rural lifestyle or speaking an indigenous language there is certainly the possibility that the next census will return an even greater proportion of the population identifying as indigenous. Other countries have experienced a resurgence of indigenous identity in recent decades: the number of people in the US identifying as indigenous doubled in the 1970s (US Bureau of the Census, 1999); the same happened in Brazil in the 1990s (Warren, 2001). What appears abundantly clear is that this is a propitious time to espouse a politics of inclusive indigenous identity. This is not to say, however, that the new indigenism does not carry with it its own problems.

It has been widely commented that the new multiculturalism in many parts of Latin America is propelled by a desire on the parts of elites to, yet again, co-opt and domesticate indigenous movements (Gustafson, 2002; Hale, 2001); but such statebased multicultural forms are used in unanticipated ways by indigenous peoples as a means to make demands on the state (Albro, 2005). In recent years and up to the time of writing there is, however, little evidence that either MAS or MIP are under any kind of control from Bolivia's social and economic elites. If this were the intended objective of the multiculturalism embarked upon by Sánchez de Lozada's administration in 1993 it can only be described as a magnificent failure, as the indigenous politics it enabled led to the dramatic downfall of Sánchez de Lozada less than ten years later.

Nevertheless, just as inclusive mestizaje contained within it the exclusion of the indian, the inclusive indigenism MAS espouses contains within it the potential for a similar form of exclusion. Morales's comments on indigenous communities are often highly idealised. Indeed, he shares with Quispe, a vision of the indigenous community where reciprocity and communal living substitute for the evils of capitalism; both invoke essentialist images of indians which are at a far remove from a quotidian reality. Quispe's understanding of who is an indian clearly excludes urban professionals and the rising indigenous merchant class; Morales invokes a rural idyll but makes this hyperreal indian accessible to a far wider public than Quispe. MAS includes mestizos and creoles among its ranks, people who Quispe is clear would not be welcome in MIP. Even as there are profound contrasts in their respective visions of indigeneity, their discourse on indigeneity is consonant with that of globalised indigenism.

If MIP and MAS are using globalised concepts of indigeneity, it is unclear how indigenous people more broadly understand their indigeneity. In the village of Pocobaya where I have conducted fieldwork since 1989, everyone speaks Aymara. In the surrounding area it is considered as something of an exception in that it has resisted the incursion of evangelical protestants and consequently the erosion of animistic beliefs; and it maintains an unusually strong sense of communal solidarity. Its traditionalism is further reinforced by the presence of a regionally famous shaman who draws clients from across the province and beyond.

People in Pocobaya do not readily describe themselves as indigenous. The Spanish term, 'indígena', is used exclusively for lowland indians whom Pocobayeños consider 
to be less civilised than they. ${ }^{10}$ Pocobayeños will sometimes describe themselves as 'indio' but despite the efforts of indianists in recent years to recuperate the term, in Pocobaya it is considered highly pejorative and most often used in the context of conversations about the time when Pocobaya was an hacienda and indio was a frequent term of abuse. One Pocobayeño commented that the term was more often used in the phrase 'indio borrego' (stupid indian) than by itself.

Neither word is, of course, Aymara and so its lack of use in everyday speech is perhaps not surprising. People do use the terms jaqi (literally 'people') and q'ara but although these terms do map onto the kinds of social distinction that can be glossed as indian/non-indian, they principally refer to a complex and ritually enforced identity which develops over time and can be lost with migration to the city (Canessa, 1998). Absent is any sense of protecting natural resources and although people do recognise a kinship with Inkas and other pre-Columbian populations, this kinship is not based on simple descent.

Pocobayeños do talk of the Pachamama and she is one of their principal deities; but they do so in terms very different from those of indigenous leaders. The Pachamama is the earth and the earth must be made offerings to release fertility; sometimes these offerings are burdensome. Pocobayeños, moreover, do not see themselves as being born of the Pachamama as expressed by Gualberto Choque or that natural gas is her breath or fart. Much less do they share an understanding of ayni with the indigenous leaders, all of who invoke it as key principal of indigenous life. For Choque ayni means 'if you are suffering and hungry I will take food from my mouth and give it to you'. ${ }^{11}$ Quispe offered a more complex definition of ayni and includes it as one of the four pillars of Aymara culture. ${ }^{12}$ Quispe outlined ayni in terms of the reciprocal labour utilised in many Andean communities for housebuilding or labouring in the fields: 'this help [ayni] has to be returned: if today someone helps you work your field, then tomorrow you would do the same for him'. ${ }^{13}$ Quispe's description of ayni would indeed be familiar to many Aymara-speaking peasants but he stressed heavily an explicitly anticapitalistic and view of ayni: 'there is no money involved in ayni: we do not count (value) money; you cannot buy the physical strength of another person. Anyone who goes to perform ayni does it with all his heart' ${ }^{14}$ (interview with author). Quispe's

10 To some extent the Bolivian State tacitly recognises that some indigenous people are more indigenous than others and is much more comfortable recognising indigenous people and their territories (Original Communary Lands) under the 1996 Land Reform in the lowland areas than it is in the highlands (Gustafson 2002: 282).

11 Jumaxa t'aqhisiskasma jani manq'añamasa utjkaspatixa, nayaxa lakajata apaqasa churamaya. Interview with author, Gualberto Choque (2005).

12 They are ayni [reciprocal labour], mink'a [exchange of labour for agricultural products], qamaña [living together], and waki [sharing land by which if one person owns the land and another provides the seed and yet another the labour, the products of the land are equally divided]. Interview with author, Felipe Quispe (2005).

13 Kuna yapunakatsa jumaxa jichhuru yanapt'ata juparu, jupaxa qharuru yanapt'xarakchitama. ). Interview with author, Felipe Quispe (2005).

14 Ukaxa janiwa janiwa qullqixa utjkiti, janiwa ukanxa akhama qullqi jakhuña utjkiti, janiwa utjkiti ch'amasa aljaña, ukasti khititixa uka ayniru sarki ukaxa taqpacha chuymampi. Interview with author, Felipe Quispe (2005). 
words are both more powerful and subtle than the English translation might suggest. 'Jakhuña' means to count but it also means to value and here both are probably intended. 'Chuyma' is most easily translated as 'heart' but it is infinitely more multilayered than such a rendition would suggest, encompassing notions of embodied personhood and even, at least in certain missionary contexts, as the core of an unacculturated Aymaraness (Orta, 2004: 181).

Morales in a 2003 interview cites reciprocity and ayni as one of the key differences between indigenous and occidental culture: 'yo te ayudo, tú me ayudas' (Sepúlveda Ruíz, 2003). There is not the space here to explain in detail how ayni operates in Andean rural communities (see Gose, 1994) and although ayni is certainly significant in rural indigenous cultures many people would find the way the word is used by indigenous leaders difficult to relate to their own perceptions of what distinguishes them from mestizos and creoles. In Pocobaya people will sometimes mention ayni as something that distinguishes them from mestizos but it is given far less prominence than the rhetoric from indigenous leaders might suggest.

Perhaps the more significant difference between leaders' rhetoric and lived reality is that relating to identity. The multifarious expressions of identity in Pocobaya and how they relate to indigeneity will be dealt with elsewhere (Canessa, n.d.) but what is significant here is that no one in Pocobaya talks of a shared political identity with, say, an Aymara nation. Pocobayeños' primary political identity is rooted in being from Pocobaya and even when pushed by a persistent anthropologist, people say 'I am an Aymara-speaker' (aymara parliritwa) rather than 'I am an Aymara' ('aymaratwa, which, in fact, does not parse). Whereas Pocobayeños will recognise their shared oppression with other poor people, this does not translate into a sense of shared ethnic identity.

Much more clearly, Pocobayeños do not feel they share an identity with urban people, whether or not they identify themselves as indigenous. That is, the 50 per cent of indigenous people who lead urban lives are not considered by rural people such as those in Pocobaya to be indigenous at all. According to the dominant Western discourse, and this appears to be shared by indigenous leaders, indigenous people are those descendants of the native populations present when the Europeans arrived. Indeed, indigenous leaders regular stress the Conquest as a pivotal moment in history whereas for people such as those of Pocobaya the Conquest is much less significant than, say, the coming of the sun. For people such as those in Pocobaya being jaqi isn't about history in the Western sense, nor is it about descent but, rather, a way of life. Migration to the urban centres leads to a loss of that identity. As Maruja Mamani (2005), a resident of Pocobaya, explained to me:

And so people (jaqi) in the past may have gone to La Paz, their children may have gone. They may stay a very long time. They could come out of Caranavi and then make their homes in La Paz. [If you were to do that] you would no longer understand Aymara - those who are born in La Paz cannot speak Aymara - and then you would be called q'ara. The children of people (jaqi) too can be called q'ara. Things can change a lot: you could 
have a lot of money and then people (jaqi) will call you misti, you're really a misti, like the q'aras. My children's children could look like q'aras; jaqi would call them q'ara That's the way it is. ${ }^{15}$

Everyone in Pocobaya was returned as 'indigenous' in the 2001 census and it is unclear to what extent the census-takers elicited the information or simply recorded it. What is clear is that Pocobayeños' sense of who they are is profoundly different from those ideas expressed by the most prominent indigenous leaders. If increasing numbers of people identify as indigenous and political capital continues to be gained from the discourses of indigeneity, people such as those living in Pocobaya may find their identities and way of life at sharp variance with those that are apparently increasingly embraced by Bolivians. Pocobayeños may find that they are inconveniently 'inauthentic' in comparison with the hyperreal indian.

Clearly more work needs to be done on the identities of rural Bolivians but even more pressing is the research that needs to be done on the indigenous identity of the urban half of the indigenous population. It is possible or even likely, with increasing urbanisation, that the urban indigenous population will become larger than the rural one. If the politics of indigeneity continue to be successful then it could become the dominant political ideology of Bolivia and the slogan of the 1950s, 'We are all mestizos now', could be replaced with 'We are all indigenous now'. If everyone is indigenous, however, it leaves little space for culturally distinct groups to organise around their indigeneity; and one of the paradoxes of the success of indigenous politics in Bolivia may be the continued marginalisation of indigenous peoples.

\section{Acknowledgement}

I am grateful to Vitaliano Huanca for his transcription of these interviews and assistance with the translation.

\section{References}

Albó, X. (1987) 'From MNRista to Katarista to Katari', in S. Stern (ed.) Resistance, Rebellion, and Consciousness in the Andean Peasant World, 18th to 20th Centuries. University of Wisconsin Press: Madison, 379-419.

Albó, X. (1991) 'El Retorno del Indio'. Revista Andina vol 1, no. 2.

15 Ukaxa ukhama nayra jaqiya akhama La Paz marka mantxiristha, wawata mantxiristha, wali jayanakata jutarakiristha ukata, uka Caranavi wasa pruwinsyanakata mistsunxaspa, uka La Pazaru utt'aspa, anchhita jumaxa janiwa aymara intintxasmati, uka nacesma La Pazana, janiwa aymara parlaña pwirxasmatixa, jumaxa q'ara satakixasmaya, ukakiya, jaqina wawapakirakiya, ukakiya q'ara sataxa, wali suma ruksuta, qullqinixarakispaya, ukata jaqixa sitaspa, misti mistirakisa, q'arjamawa, wawajaxa wawanixaspaxa, q'arana wawapaxaspasa jalla ukhama, ukakiya, jaqikiya q'aranakawa sasa, uka q'araxa mistina wawapaxa jaqina wawapakirakikiya, ukhamawa. 
Albó, X. (1995) “And From Kataristas to MNRistas” in Donna Lee Van Cott, ed., Indigenous Peoples and Democracy in Latin American. St. Martin's Press: New York.

Albó, X. (2002) 'Bolivia: From Indian and Campesino Leaders to Councillors and Parliamentary Deputies', in R. Sieder (ed.) Multiculturalism in Latin America: Indigenous Rights, Diversity and Democracy. Palgrave: New York, 74-102.

Albro, R. (2005) 'The Indigenous in the Plural in Bolivian Oppositional Politics'. Bulletin of Latin American Research 24(4): 433-453.

Bengoa, J. (2000) La emergencia indígena en América Latina. Fondo de Cultura Económica: México City and Santiago de Chile.

Bigenho, M. (2005) 'Making Music Safe for the Nation: Folklore Pioneers in Bolivian Indigenism', in A. Canessa (ed.) Natives Making Nation: Gender, Indigeneity and the Nation-State in the Andes. University of Arizona Press: Tucson, 60-80.

Brysk, A. (2000) From Tribal Village to Global Village: Indian Rights and International Relations in Latin America. Stanford University Press: Stanford.

Canessa, A. (1998) 'Procreation, the Person and Ethnic Difference in Highland Bolivia'. Ethnos 63(2): 227-247.

Canessa, A. (2000) 'Contesting Hybridity: Evangelistas and Kataristas in Highland Bolivia'. Journal of Latin American Studies 32(1) 115-144.

Canessa, A. (2004) 'Reproducing Racism: Schooling and Race in Highland Bolivia'. Journal of Race and Education 7(2): 185-204.

Canessa, A. (n.d.) 'Identities, Indigeneities: Self and Representation in an Andean Community'. Paper delivered at the American Anthropology Association Conference, Chicago, 2003.

Castells, M. (2000) The Rise of the Network Society (2nd edn), Blackwell: Oxford.

Choque, R. (1992) Educación indígena: ¿ciudadanía o colonización? Aruwiyiri: La Paz.

Dangl, B. (2003) 'An Interview with Evo Morales: Legalising the Colonisation of the Americas'. Counterpunch [WWW document]. URL http://www.counterpunch.org/ dangl12022003.html [accessed November 2004].

Davis, S. and Williams, P. (2001) Promoting the Development of Indigenous Peoples in Latin America. World Bank: Washington, DC.

Eriksen, T. (1993) Ethnicity and Nationalism. Pluto: London.

Evo Morales (2005) URL http://www.evomorales.net [accessed 4 July 2005].

Forero, J. (2004) 'Where the Incas Ruled, Indians are Hoping for Power'. The New York Times, 17 July.

Goldstein, D. (1997) 'Re-Imagining the Jew in Hungary: The Reconstruction of Ethnicity through Political Affiliation', in H.-R. Wicker (ed.) Rethinking Nationalism and Ethnicity: The Struggle for Meaning and Order in Europe. Berg: Oxford and New York, 193-210.

Gose, P. (1994) Deathly Waters and Hungry Mountains: Agrartian Ritual and Class Formation in an Andean Town. University of Toronto Press: Toronto.

Gow, D. and Rappaport, J. (2002) 'The Indigenous Public Voice: The Multiple Idioms of Modernity in Native Cauca', in K. Warren and J. Jackson (eds) Indigenous Movements, Self-Representation, and the State in Latin America. University of Texas Press: Austin, 47-80.

Graham, R. (ed.) (1990) The Idea of Race in Latin America 1870-1940. University of Texas Press: Austin.

Graham, L. (2002) 'How should an indian speak?' in Warren, Kay and Jean Jackson (eds) Indigenous Movements, Self-Representation, and the State in Latin America. University of Texas Press: Austin.

Gustafson, B. (2002) 'Paradoxes of Liberal Indigenism: Indigenous Movements, State Processes, and Intercultural Reform in Bolivia', in D. Maybury-Lewis (ed.) The Politics of Ethnicity: Indigenous Peoples in Latin American States. Harvard University Press: Cambridge, 267-306. 
Hale, C. (2002) 'Does Multiculturalism Menace? Governance, Cultural Rights and the Politics of Identity in Guatemala'. Journal of Latin American Studies 32(1), 115-144.

Harris, O. (1988) 'La pachamama: significados de la madre en el discurso boliviano', in Latinoamericanas: diez ensayos en una historia colectiva. Lima: Flora Tristán, 7-75.

Harris, O. (1995) 'Ethnic Identity and Market Relations: Indians and Mestizos in the Andes', in O. Harris, B. Larson and E. Tandeter (eds), Ethnicity and Markets in the Andes: Indian Economies and Commercial Adaptations 16th-20th Centuries. Duke University Press: Durham, 351-390.

Hodgson, D. (2002) 'Comparative Perspectives on Indigenous Rights Movements in Africa and the Americas'. American Anthropologist 104(4): 1037-1049.

Hylton, F. (2003) 'La guerra en irak: la nueva cara de la globalización'. Soberania 3(15).

Instituto Nacional de Estadísticas de Bolivia/UMPA (2003) Bolivia: Características sociodemográficas de la población. INE: La Paz.

Laurie, N., Andolina, R. and Radcliffe, S. (2002) 'The Excluded Indigenous? The Implications of Multi-Ethnic Policies for Water Reform in Bolivia', in R. Sieder (ed.) Multiculturalism in Latin America: Indigenous Rights, Diversity and Democracy. Palgrave: New York, 252-276.

Lee, R. (2003) 'Indigenous Rights and the Politics of Identity in Post-Apartheid Southern Africa', in B. Dean and J. Levi (eds) At the Risk of Being Heard: Identity, Indigenous Rights, and Postcolonial States. The University of Michigan Press: Ann Arbor, 80-111.

Los Tiempos [La Paz] (2004) 'El MAS vuelve a las calles para exigir la nacionalización del gas', 31 August.

Martínez Cobo, J. (1986) The Study of the Problem of Discrimination Against Indigenous Populations (Vol. 1-5). United Nations Document E/CN.4/Sub.2/1986/7. United Nations: New York.

Maybury-Lewis, D. (2003) Indigenous Peoples, Ethnic Groups and the State. Harvard University Press: Cambridge.

Melucci, A. (1989) Nomads of the Present. Hutchinson: London.

Movimiento al Socialismo (2005) http://www.masbolivia.org [accessed 4 July 2005].

Niezen, R. (2003) The Origins of Indigenism: Human Rights Issues and the Politics of Identity. University of California Press: Berkeley.

Orta, A. (2004) Catechizing Culture: Missionaries, Aymara, and the 'New Evangelization'. Colombia University Press: New York.

Patzi, F. (1999) Insurgencia y sumisión: movimientos indígeno-campesinos (1983-1998). Muela del Diablo Editores: La Paz, Bolivia.

Qhispe Wanka, F. (1990) Tupak katari vive y vuelve ... icarajo! (La Paz), 140-143.

Ramos, A. (1994) 'The Hyperreal Indian'. Critique of Anthropology 14(2): 153-171.

Sepúlveda Ruiz, L. (2003) 'La hoja de coca, una bandera de lucha. Entrevista con Evo Morales'. Punto Final, May.

Stavenhagen, R. (2002) 'Indigenous Peoples and the State in Latin America: An Ongoing Debate', in R. Sieder (ed.) Multiculturalism in Latin America; Indigenous Rights, Diversity and Democracy. Palgrave Macmillan: Houndmills, Basingstoke and New York, 24-44.

Stephen, L. (2003) 'Indigenous Autonomy in Mexico', in B. Dean and J. Levi (eds), At the Risk of Being Heard: Identity, Indigenous Rights, and Postcolonial States. The University of Michigan Press: Ann Arbor, 191-216.

Touraine, A. (1988). Return of the actor. Social theory in the post-industrial society. University of Minnesota Press: Minneapolis.

US Bureau of the Census (1999) Race and Hispanic Origin of the Population by Nativity: 1850 to 1990 [WWW document] internet release date: 9 March 1999. URL http:// www.census.gov/population/www/documentation/twps0029/tab08.html [accessed 22 October 2004]. 
Van Cott, D. L. (2002) 'Constitutional Reform in the Andes: Redefining Indigenous-State Relations', in R. Sieder (ed.) Multiculturalism in Latin America; Indigenous Rights, Diversity and Democracy. Palgrave Macmillan: Houndmills, Basingstoke and New York, 45-67.

Vinelli, N. (2002) 'Entrevista a Felipe Quispe, el mallku. Los ayllus y el capitalismo son sistemas antagónicos'. Resumen [Buenos Aires].

Wade, P. (1997) Race and Ethnicity in Latin America. Pluto: London.

Warren, J. W. (2001) Racial Revolutions: Anti-Racism and Indian Resurgence in Brazil. Duke University Press: Durham and London.

Warren, K. and J. Jackson (eds) (2002) Indigenous Movements, Self-Representation, and the State in Latin America. University of Texas Press: Austin.

Wearne, P. (1996). Return of the Indian. Conquest and Revival in the Americas. Cassell: London

Wright, W. (1990) Café con Leche: Race, Class and National Image in Venezuela. University of Texas Press: Austin.

\section{Interviews}

Felipe Quispe (2005) La Paz, 18 April.

Gualberto Choque (2005) La Paz, 15 April.

Maruja Mamani (2005) Pocobaya, April. 